\title{
Psychological Competencies and 100 Meter Runner Student Athletes' Performance
}

\author{
Rachman Widohardhono ${ }^{1}$, Nurhasan ${ }^{2}$, Edy Mintarto ${ }^{3}$, Miftakhul Jannah ${ }^{4}$, \\ 1,2,3,4. Universitas Negeri Surabaya, Surabaya, Indonesia
}

\begin{tabular}{|c|c|}
\hline 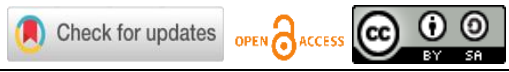 & DOI : https://doi.org/10.46245/ijorer.v2i6.173 \\
\hline Sections Info & ABSTRACT \\
\hline Article history: & This research aims to analyze the suitability of the theoretical model of the \\
\hline Submitted: November 1, 2021 & psychological competencies model b of the 100 -meter runner student athletes \\
\hline Final Revised: November 4, 2021 & with the empirical model. This study uses a quantitative approach. Total 65 \\
\hline Accepted: November 28, 2021 & (50 men and 15 women) 100-meter runner student athletes who participated \\
\hline Published: November 30, 2021 & in the national athletic championships. Instruments uses the Psychological \\
\hline Keywords: & Competency Scale and time records documentation data on the results of \\
\hline Psychological competencies & national championships. Data analyzed using partial least square (PLS). The \\
\hline Performence & results of the inner model test show a Q-square value of $0.919(>0.00)$. It \\
\hline Student Athlete & means that there was suitability of the theoretical model of psychological \\
\hline Sprinter & competency of 100 -meter runner student athletes' with the empirical model. \\
\hline Movement task & The R-square value of performance is 0.881 . It means that the 100 -meter \\
\hline 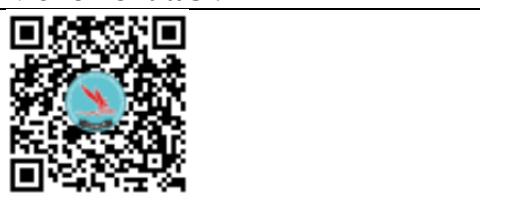 & $\begin{array}{l}\text { runner student athletes' performance were influenced by psychological } \\
\text { competencies by } 88,1 \% \text {. These findings have implications for the selection and } \\
\text { coaching of } 100 \text {-meter runner student athletes. Further research needs to } \\
\text { design mental skills training comprehensively based on psychological } \\
\text { competencies }\end{array}$ \\
\hline
\end{tabular}

\section{INTRODUCTION}

Sport is one of the activities that are the pillars of the realization of a prosperous nation. In realizing this, athletes with optimal abilities are needed. A structured coaching system is needed and has a clear vision and mission to strive for sports achievements that student-athletes will achieve. According to Assalam et al. (2015), conceptually, the components of the coaching system (objectives, athletes, facilities and infrastructure, methodologies, evaluations, etc.) are essential to use in national, and club sports were coaching. Successful sports development that produces maximum achievements and contributes to increasing community economic activity, as a medium for promoting the nation on the international stage, stimulating an increase in the country's foreign exchange earnings, and fostering a sense of nationalism in all Indonesian citizens (Jopang, 2018).

Observing the achievement data reveals that the selection and coaching in Indonesia have not taken place as they should. According to Hidayatullah (2009), the cause of Indonesia's achievement is not optimal because, among others, the selection and guidance have not been directed and apply science. Student-athletes significant challenges can even increase stress and academic difficulties (Parker et al., 2018).

In fact, in Indonesia, the role of sport psychology has not been optimal. There are no studies in Indonesia that have formulated a coaching model. The USA and the United States Olympics involve sports psychologists in selecting and coaching athletes participating in the Olympics representing the USA. The application of the coaching system in Canada involves psychological factors in the selection and coaching process (Baker et al., 2020). The description above is in line with sports psychology research on 
sports performance. This research was carried out by Csáki et al. (2017), proving that psychological factors make the most significant contribution in determining success for athletes compared to other factors. A similar opinion was expressed by (Jannah et al., 2015) which stated that the main key to success in athletes is psychological factors. Concerning psychological factors, one of which is the ability to set goals. Goal setting essentially affectsports achievement (Kyllo \& Landers, 2016; Weinberg, 2013). Jannah (2012) states that athletes must have goal-setting abilities to be able to achieve targeted performance. Through goal-setting capabilities, 100-meter runners will develop high motivation to achieve the specified version.

Another research is about concentration in the field of sports. Concentration is an essential psychological factor and can determine athlete achievement (Afifuddin et al., 2020). Concentration is the ability of athletes to focus their attention and thoughts on information that is important for their successful performance in competition (Jannah, 2017b). When athletes perform sports movements, and their concentration is disturbed, especially during competition, it can cause various problems. These problems include reduced movement accuracy (Jannah, 2017a; Lu et al., 2021). Other effects are disrupted when implementing strategies that are not appropriate and have an impact on athletes' confidence. The final effects of athletes being hampered in achieving peak performance (Rooks et al., 2017).

Similarly, Lavallee et al. (2020) said that concentration is essential for achieving optimal performance. Engagement helps athletes to be ready to compete both physically and psychologically. A similar statement states that athletes need to focus on achieving optimal performance (Qiu et al., 2018). An example of the importance of concentration on runners, Tim Montgomery, sprinter holding the title of the world's fastest man, after setting a 100-meter run record with a time of 9.78 seconds. In addition to physical factors, it was stated that Montgomery had a high level of concentration so that it could break the world record for Maurice Greene in June 1999 in the city of Athens, Greece. Another example from Indonesia, 100 meter runner Lalu Muhammad Zohri, broke the national record in Doha, Qatar after setting a time of 10.13. Zohri admits that concentration plays an important role in performance when selecting a new record after Suryo Agung, which is 10.17 (Sawitri, 2019).

The runner's achievement is influenced by self-talk. Review about self-talk and specific sport has been carried out by van Raalte et al. (2016) said that self-talk affects sports performance. Self-talk is needed to manage the athlete's mind during competition (van Raalte et al., 2016). Positive self-talk will affect self-confidence to improve athlete performance (Putra \& Jannah, 2017). Negative self-talk makes athletes helpless (Hatzigeorgiadis et al., 2014). Athletes' self-confidence requires management during matches so that athletes focus on achieving the specified performance (Machida et al., 2017). This is important so that the expected performance can be achieved (Afrouzeh et al., 2020). Athletes need to regulate emotion to improve physical and mental abilities to achieve optimal performance (Azizah \& Jannah, 2020; Jannah \& Dewi, 2021; Scharfstein \& Gaurf, 2013). The ability to regulate emotions forms athletes to have strategies that can be used as an effort to control emotions ((Mones, 2003; Rogier et al., 2019; Scharfstein \& Gaurf, 2013). Emotion regulation plays a central role in regulating the mood and mood disorders that plague athletes. According to Gross (2014) and Planalp (2015) emotion regulation is how an individual's skills are to control, control, and regulate the kinds of emotional reactions he feels to achieve goals. 
During the competition, recognizing oneself, including one's emotions,s important (Uphill et al., 2012). The ability to identify and regulate emotions allows athletes to understand their best potential. This is effectively used as energy to achieve the targeted performance (Jannah, 2020). An example of the importance of emotional regulation in runners, Usain Bolt, the holder of the title of the world's fastest man, broke the world record in the 100 meters run with 9.69 seconds, August 2008 in Beijing. In addition to physical factors, Bolt has high self-confidence and good emotional regulation skills. Bolt was so confident he looked to have waved his hand with his face towards the stands 20 yards from the finish line. In addition, Bolt stated that he must be in a favorable condition (Belva, 2008).

Sports psychology studies on psychological factors that support the achievement of 100-meter student-athlete runners are still not comprehensive and not interrelated. Therefore, the theoretical construct of psychological factors that support the achievement of 100-meter student-athletes runners has not been adequately explained. No one has studied competence yet. Whereas concerning athlete performance, it relates to athletes who are competent for efficient and effective implementation. This discussion is about competence. Competence describes the self-concept, motives, values, knowledge, and skills athletes possess when competing. The complexity of the psychological aspects of forming psychological competence requires a model to make it easier to understand. Shet et al. (2019) stated that the model is a miniature of reality, as a description or analogy to facilitate complex understanding. The competency model serves as an explanation of how competence affects performance, psychological aspects related to athletes according to motion tasks in order to produce effective performance. This psychological competency model requires research that produces theoretical models and develops and tests models a priori (von Treuer \& Reynolds, 2017). This research aims to test the suitability of the theoretical model of psychological competence of 100-meter student athlete runner with empirical data.

\section{RESEARCH METHOD \\ General Background}

The research used is quantitative. The procedure is carried out in the preparation of a theoretical model. This research has variables 100-meter runner achievement, goal setting, motivation, persistence, emotion regulation, concentration, self-confidence, and self-talk. All variables are latent because they are not measured directly but based on manifest variables or indicators (Ramayah et al., 2018). In model analysis, exogenous variables are known, also known as source variables or independent variables. Other variables in the model do not predict this variable. In the model, exogenous variables are described as not addressed by a line with one arrowhead. This research's exogenous variables are goal setting, motivation, emotion regulation, concentration, self-confidence, and self-talk. In addition, the model analysis is also known as endogenous variables. Endogenous variables are variables that are predicted by several or one other variables. In the model, the endogenous variable is the variable addressed by the line that has one arrowhead. In this research, the endogenous variable is the achievement of the 100-meter runner student-athlete.

\section{Sample}

Subjects of this research are 65 (50 men and 15 women) student-athletes of 100 meters sprinters who had criteria as Indonesian's 100 meters sprinter, who participated in the 
official championship by the National Track and Field Federation when this research occurred.

\section{Instrument}

The data collection tools of this research are data documentation and psychological competency scale. Documentation data is used to obtain performance data for 100 meter student athletes runner. Data in the form of race results issued by National Track and Field Federation, namely the time record from start to finish, is expressed in seconds. The data used is the best performance data during the competition. This refers to the national sports week limit rules taken based on the best time records in a particular race.

The psychological competence variable was measured using a psychological competence scale with a behavioral approach method. This is chosen to avoid faking by the subject. Subjects were asked to choose based on the suitability of their behavior alternative behavior in the form of leveling. Based on what is stated in the operational definition of psychological competence, the higher the number level, the lower the psychological competence, and vice versa. The scoring is carried out in this research to synchronize with performance data, which shows that the smaller the number, the higher the subject's performance.

Development of competency measurement tools: three people were selected in this research as subject matter experts, track and field coach, psychometrician, and sports psychologist. Based on the three experts, the effective and ineffective behavior was selected related to the construct to be measured and determined the critical incident technique. These data are converted into the dimensions of the 100-meter runner's motion task, ensuring no overlap between the measurements to be measured. The indicator is a manifest of the sizes to be measured.

In the instrument trial, the results of the 10-item difference power test calculation on the psychological competence scale of the 100-meter runner have a different power index between 0.341 to 0.641 . It shows all values above 0.3 . Instrument reliability testing was carried out using the calculation of the Cronbach's alpha coefficient score of 0.841 . Based on these results, all items considered valid and reliable can be used as items in the research instrument.

\section{Data Analysis}

Data were analyzed using the Partial Least Square model (PLS). Testing the structural or inner model was carried out to explore the relationship between variables, significance value, and R-square of the research model. The structural model was tested through Rsquare for the dependent variable, $t$-test, and the value of the coefficients of the structural path parameters (Purwanto \& Sudargini, 2021; Ringle et al., 2020). The structural model was tested using the goodness of fit model. It shows the difference between the observed score and the estimated score in the model. The goodness of fit or commonly called conformity testing, is evaluated using Q-square predictive relevance. The recommended Q-square value is above 0.00 (Ringle et al., 2020). The Q-square formula is:

$$
\mathrm{Q}^{2}=1-\left(1-\mathrm{R}_{1}^{2}\right)\left(1-\mathrm{R}_{2}^{2}\right) \ldots \ldots\left(1-\mathrm{Rp}^{2}\right)
$$


This method is considered because the research model indicates more than one dependent variable, small samples (less than 100 samples), andhe abnormally multifarious data (Ringle et al. , 2020).

\section{RESULTS AND DISCUSSION}

Testing of the structural model or inner model was carried out to analyze the relationship between variables, significance value, and R-square of the research model. The structural model was tested through R-square for the dependent variable, $t$-test, and the value of the coefficients of the structural path parameters (Ringle et al., 2020). The results of the analysis of the hypothesized model data are as follows:

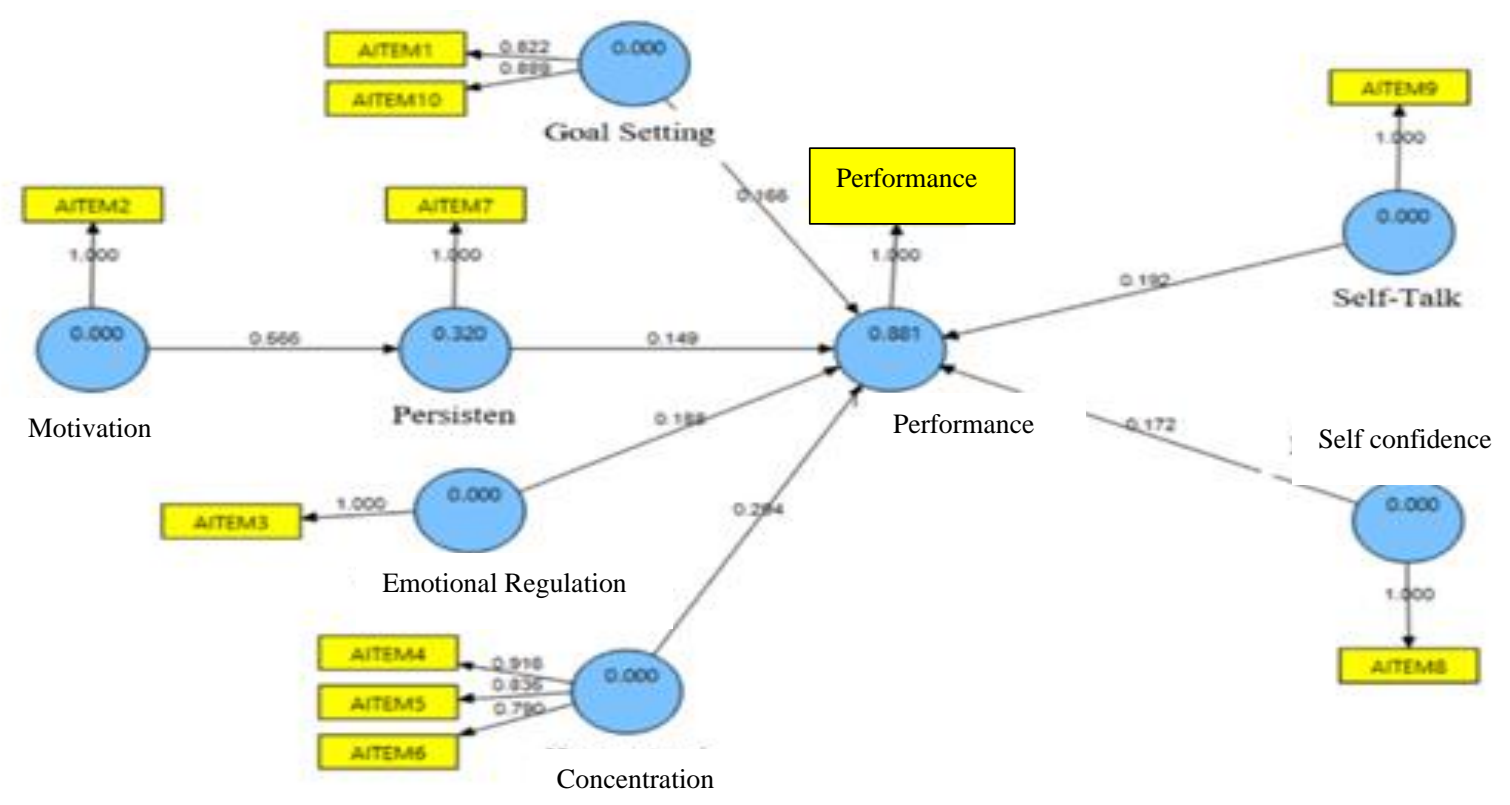

Figure 1. Model of psychological competencies of 100-meter runner studentathletes.

The assessment of the model through PLS begins with the R-square of each dependent variable. The R-square value is used to assess the effect of certain independent variables on the latent dependent variable whether it has a substantive impact. Based on the model above, the R-square value of the achievement variable is 0.881 . This means that the achievement variable is influenced by the goal-setting, persistence, emotion regulation, concentration, self-confidence, and self-talk variables together by $88.1 \%$. The test of the suitability of the theoretical model with the empirical is analyzed by calculating the Qsquare predictive relevance as follows:

$$
\begin{aligned}
\mathrm{Q}^{2} & =1-\left(1-\mathrm{R}_{\mathrm{PER}}{ }^{2}\right)\left(1-\mathrm{R}_{\mathrm{PRES}^{2}}\right) \\
& =1-(1-0,320)(1-0,881) \\
& =1-(0,680)(0,119) \\
& =1-0,081 \\
& =0,919
\end{aligned}
$$


Based on these calculations, the value of $\mathrm{Q}^{2}$ obtained is 0.919 . This proves that the model formed is reasonably good. This means that the theoretical model developed is following the empirical data. This research provides empirical evidence that there is a match between the theoretical model of psychological competence based on the 100meter runner student-athlete with empirical data. The student athlete's performance is a manifestation of the psychological competence of the student-athlete in collaboration with environmental factors. The process of determining the behavior that appears involves cognitive processes in student-athletes. For example, during training before a competition, one psychological aspect that arises is the motivation to win. Social aspects such as when practicing fellow student-athletes are unable to attend. These internal and external conditions interact with each other. Whatever the student-athletes decide at that time has gone through a cognitive process. Student-athletes may persist in training, or they may be reluctant to train. These behaviors are coupled with the final result is a race that produces a performance.

Goal setting ability can be interpreted as designing or setting goals to be achieved while evaluating them (Weinberg, 2013). Achievement targets are goals that sprinters must achieve. Achievement targets are more effective then athletes participating in setting targets (Kyllo \& Landers, 2016). Athletes are expected to have the ability to set targets so that they have an effort to achieve them. Achievement targets make their activities during practice have a clear direction. According to Smith and Ntoumanis (2014), to motivate individuals to increase their performance achievement is to clearly explain the target, what must be started and continued to be done.

Efforts to achieve the targets set to be effective require feedback. Feedback is useful for individuals to know what efforts have been made and the accuracy of the strategies used to reach the predetermined targets. When individuals find that their targets are not being met, they will increase their efforts to achieve them (Kyllo \& Landers, 2016; Weinberg, 2013). A sprinter who can set goals for himself will be motivated to achieve his goals. He will know what effort to put in, as well as how often he will practice. In addition, this ability will increase self-discipline in practice (Burton, 2016). According to Smith and Ntoumanis (2014), athletes who have specific goals will be more disciplined in practice because they know the purpose of the exercises they do.

This research proves that the ability to regulate emotions has a positive effect on the performance of sprinters. The ability to control emotion attempts to change the good or bad valence between the individual and the environment in coping mood regulation and psychological defense(Planalp, 2015). A sprinter needs good emotional regulation to reduce negative emotions and tension caused by various situations when competing. His ability to regulate emotions can help him control emotions from multiple influences of both internal and external conditions (Gross, 2015). When sprinters can regulate their emotions well, it will affect their competing movement tasks (Roth et al., 2019). In addition, athletes need social support for emotion regulation strategies (Lavallee et al., 2020). The ability to manage emotions in sprinters is essential. Conditions at the start, in addition to requiring concentration, sprinters must also regulate their feelings. Sprinters are necessary to relax, manage anxiety, raise their confidence so that all their movements are on cue and don't make a bad start.

These results align with research conducted by (Uphill et al., 2012), who concluded that regulating emotions affects athlete performance. In addition, this is in line with (Scharfstein \& Gaurf, 2013), which states that the ability to reduce negative emotions and generate positive emotions in competing will improve athlete achievement. Through 
enjoyment, athletes will be more optimal in carrying out movements. According to Lea et al. (2018), positive emotions will increase attention. So that individuals will enjoy what they do. Management of positive emotions is an individual strategy to increase resilience in dealing with stressors (Seaton et al., 2018). This is what is able to boost sprinters with optimal performance.

Emotional management can be understood as a process that activates thoughts, behaviors, and feelings continuously to achieve the goals that have been set. For this reason, emotion regulation is often described as a cycle in which feedback from previous behavior is used to make adjustments in current endeavors. The process of emotional rehabilitation in sprinters begins with situation selection. In this condition, the athlete selects internal and external stimuli. Internal stimuli include anxiety, self-concept, and physical state, while external stimuli are spectators, other athletes, coaches, and field situations (Uphill, McCarthy \& Jones, 2012). In this phase, the athlete selects various existing stimuli by bringing him closer to conditions that make him comfortable and away from situations that make him uncomfortable.

When a sprinter has focused his attention on a situation, there will be cognitive changes in him. This cognitive change is a form of sprinter's effort in assessing the various stimuli encountered. Assessment of these various stimuli will lead to response modulation. The emotional response of a sprinter is influential when he manifests his behavior in his movement task. Fulfillment of good motion tasks will be able to boost the achievement of optimal performance, and vice versa.

Concentration has a positive effect on the performance of sprinters. This is in line with the opinion of (Afifuddin et al., 2020; Gustian, 2016) that concentration affects athlete achievement. The ability to control thought processes and concentrate on the task at hand is universally recognized as the essential key to sports achievement (Lu et al., 2021). In general, athletes have optimal abilities and energy that can focus their attention on moving the sport they do (Qiu et al., 2003). Various problems can arise if the athlete's concentration is disturbed when performing sports movements, especially in competitions. These problems such as reduced movement accuracy, unable to implement strategies because they do not know what to do so that the athlete's confidence is reduced or even lost. In the end, athletes find it difficult to achieve optimal performance (Love et al., 2018). Similarly, Lavallee et al. (2020) state that concentration is essential for achieving peak performance.

According to Lavallee et al. (2020), there are five principles to describe the effectiveness of concentration to support sports achievement. The first principle, athletes must prepare themselves mentally to concentrate. The second principle is to focus on only one task at a time. The third principle is congruence between what is done and what is thought. The fourth principle, the athlete will lose concentration when thinking about factors that he cannot control. The fifth principle is that if an athlete experiences panic, he must focus on his task by ignoring the alarm experienced. Athletes who are distracted during a race will have impaired accuracy of motion. The efficiency of the motion task becomes impaired. In the end, it affects his performance. For example, when it occurs at the start, athletes can be late to the starting line compared to other sprinters. Given the short distance traveled, then this can be fatal to the performance of sprinters.

Based on the conditions at the start, the ability to concentrate is needed by fast runners. The sprinter must focus on the signal given by the starter, ignoring other distracting information, so as to be able to make an effective start. Loss of concentration in the starting conditions can be fatal such as a wrong start, may cause the athlete to be 
disqualified. In addition, during the running movement, sprinters are required to have the ability to focus on the track and motion to quickly reach the finish line. At the time of running, athletes are required to run in accordance with the track (on the track), it is declared invalid if they grab the track line of another athlete.

This research proves that persistence in training has a positive effect on the achievement of sprinters. This is in line with Rodrigue et al. (2020), which states that to pursue achievement requires persistent effort. Fast runners are required to be diligent and tenacious in practicing. The physical exercise program that the trainer makes for him must be carried out every day according to his schedule and load. When the athlete does not run the program, it will affect movement and technique ability to carry out their duties as a sprinter. So this is what, according to Bompa \& Buzzichelli (2019), elite athletes tend to do physical exercise at least $95 \%$ of the program that has been made for them.

Persistence is needed to maintain motivation to achieve the predetermined achievement targets(Rodrigues et al., 2020). Persistence is a behavior that is continuously done to achieve goals. According to England et al. (2019), persistence is preceded by a will. Willingness is important because it is the driving motivation that makes people have the energy to achieve goals. Willingness will encourage individuals to persist and be persistent in pursuing the desired goals. A sprinter who is driven to be the best in his sport is usually able to pressure himself always to perform optimally. Likewise, when undergoing training, athletes will be happy to undergo the training portion by themselves.

The analysis results show that self-confidence to compete has a positive effect on the achievement of sprinters. This is in line with (Afrouzeh et al., 2020; Machida et al., 2017), which proves that self-confidence affects the performance of athletes. Through symbolizing, athletes can predict what actions must be taken to be able to achieve optimal performance. This is reinforced social cognition theory by Bandura (Beauchamp et al., 2019), who argues that self-confidence will be formed in a reciprocal triangle relationship between personal characteristics (person), behavior patterns (behavior), and environmental factors (environment). This relationship is complex and long, because of the interaction of these personal and social elements.

A person's behavior results from a person's interpretation of the environment faced by referring to his beliefs, experiences, motivations, moral values, and expectations. The interpretation results occur after the understanding process (cognitive process) of the individual and the behavior (Burton, 2016; Eysenck \& Keane, 2015).

A person's behavior is determined based on the results of the individual's interpretation of environmental stimuli (in this case, it can be in the form of people, objects, or problems in the environment where he is). Therefore, the more a person interacts with various settings (situations, problems, conditions), the more appropriate the interpretation results. Thus their behavior or performance will be more sensitive and responsive. Sprinters will adapt quickly and manage their emotions to be positive. When a sprinter's emotions become positive, he will happily carry out his activities. This encourages athletes to be persistent in training.

According to Said and Jannah (2018), self-confidence is an essential aspect of personality in daily activities. Self-confidence can make a person able to behave as needed to get the expected results. For example, a runner enjoys the competition he participates in because he believes that when he is on the line of his running trajectory and remains at his pace, he enters the fastest finish line. 
Self-confidence can be developed through modeling and vicarious experience, social persuasion and positive feedback, and physical and psychological encouragement. For sprinters who have experience competing more often, meeting with various competition opponents, the situation is that they represent the club, region, province, and country. The different race processes make the sprinter test his abilities, finding and having confidence in his abilities. It also has a close relationship with performance outcomes (Gencer \& Öztürk, 2018). Confidence is essential for sprinters to express their physical, technical, and strategic skills acquired while training in a competition. Without the confidence to compete, the physical abilities gained during practice are not optimally expressed. Self-confidence will encourage athletes' cognitive processes to apply effective strategies to win competitions (Machida et al., 2017). In addition, past successes affect self-confidence to compete. When an athlete can achieve the desired performance, pride grows in him and makes him more confident in competing. His self-confidence arises because he can realize his expectations (Said \& Jannah, 2018)

Confident people have realistic expectations and can accept themselves and remain positive even when some of those expectations are not met. Most people feel more confident in certain areas than in others. Self-confidence is based on a realistic belief in the abilities possessed by the individual. When individuals feel low self-esteem, individuals do not succeed in realizing their true abilities. Individuals avoid taking on new challenges. In this way, low self-esteem can lead to an unrealistic lack of confidence, limiting our ability to give our best.

This research proves that self-talk has a positive effect on the performance of sprinters. Self-talk is one of the common psychological strategies used by athletes. In analytical research proves that self-talk impacts athlete performance (Hatzigeorgiadis et al., 2014). Mallett \& Hanrahan (1997) conducted self-talk research on elite 100-meter sprinters who found the effectiveness of self-talk on performance in the $100-\mathrm{m}$ race. A race plan is designed with the correct use of cues for the three-race segments. Specifically, participants were instructed to use the "push" button for the acceleration phase (0-30 meters), the "heel" cue for the maximum speed phase (30-60 meters), and the "claw" cue for the endurance phase. Speed (60-100 meters). The use of self-talk proved a significant reduction in travel time.

Self-talk is needed to train athletes mentally to be better prepared when practicing or competing. Self-talk raises memories about the strengths or abilities possessed by athletes (Hatzigeorgiadis et al., 2011; Putra \& Jannah, 2017). In addition, it ensures that with these advantages, athletes are also able to overcome their limitations. The self-talk raises internal awareness. That is, experiences, thoughts, and beliefs are internalized as self-talk(van Raalte et al., 2016). Self-talk can carry a person's feelings, perceptions, and attributions. An athlete who explodes with (for example, "I failed") may hear themselves and better understand their frustrations. Once recognized, he can then use reactive selftalk to direct himself and improve his performance (e.g., "If I move my legs and go faster, nothing will get past me").

\section{CONCLUSIONS}

This research concludes a match between the psychological competence theory model of student-athletes running 100 meters with empirical data. The R-square value of performance is 0.881 . It means that the achievement of 100 -meter running athletes is influenced by psychological competence by $88.1 \%$. This finding has implications for the selection and coaching of 100-meter runner athletes based on their psychological 
competence. The limitation of this research is that the instrument only uses self-report, which is very likely to be subjective. So that in future research, it is necessary to research with tools that are assessed by the coach so that it can be more objectified.

\section{REFERENCES}

Afifuddin, T., Hidayah, T., \& Handayani, O. W. K. (2020). The effect of relaxation exercises, and concentration on shooting free throw results after maximum training on basketball team at integrated islamic junior high school bina amal semarang. Journal of Physical Education and Sports, 9(1), 87-94.

Afrouzeh, M., Konukman, F., Lotfinejad, M., \& Afroozeh, M. S. (2020). Effects of knowledge of results feedback on more accurate versus less accurate trials on intrinsic motivation, selfconfidence and anxiety in volleyball serve. Physical Culture and Sport, Studies and Research, 87(1), 24-33. https://doi.org/10.2478/pcssr-2020-0016

Azizah, F. F., \& Jannah, M. (2020). Pengaruh meditasi otogenik terhadap regulasi emosi pada atlet anggar. Charachter, 07(02), 62-67.

Baker, J., Schorer, J., \& Wattie, N. (2017). Compromising talent: Issues in identifying and selecting talent in sport. Quest, 70(1), 48-63. https:// doi.org/10.1080/00336297.2017.1333438

Beauchamp, M.R., Crawford, K.L., Jackson, B. (2019) Social cognitive theory and physical activity: Mechanisms of behavior change, critique, and legacy. Psychology of Sport $\mathcal{E}$ Exercise, 42, 110-117. https://doi.org/10.1016/j.psychsport.2018.11.009.

Bompa, T. O., \& Buzzichelli, C. A. (2019). Periodization: Theory and methodology of training. Journal of Chemical Information and Modeling, 53(9), 1689-1699.

Burton, D. (2016). Winning isn't everything: Examining the impact of performance goals on collegiate swimmers' cognitions and performance. The Sport Psychologist, 3(2), 105-132. https://doi.org/10.1123/tsp.3.2.105

Csáki, I., Szakály, Z., Fózer-Selmec, B., Kiss, S. Z., \& Bognár, J. (2017). Psychological and anthropometric characteristics of a Hungarian Elite Football academy's players. Physical Culture and Sport, Studies and Research, 73(1), 15-26. https://doi.org/10.1515/pcssr-20170002

England, B.J., Brigati, J.R., Schussler, E.E. \& Chen, M.M. (2019). Student anxiety and perception of difficulty impact performance and persistence in introductory biology courses. CBE - Life Sciences Education, 18(2), 1-13. https://doi.org/10.1187/cbe.17-12-0284

Eysenck, M. W., \& Keane, M. T. (2015). Cognitive psychology a student's handbook (Seventh Ed). Psychology Press.

Gencer, E.. \& Arda, Öztürk, A. (2018). The Relationship between the Sport-Confidence and the Coach-Athlete Relationship in Student-Athletes. Journal of Education and Training Studies, $6(10), 7-14$

Gross, J. J. (2014). Handbook of Emotion Regulation (Second). Ney York: The Guilford Press.

Gross, J. J. (2015). Emotion regulation: Current status and future prospects. Psychological Inquiry, 26(1), 1-26. https://doi.org/10.1080/1047840X.2014.940781

Gustian, U. (2016). Pentingnya perhatian dan konsentrasi dalam menunjang penampilan atlet. Performa Olahraga, 1(1), 1-11.

Hatzigeorgiadis, A., Galanis, E., Zourbanos, N., \& Theodorakis, Y. (2014). Self-talk and competitive sport performance. Journal of Applied Sport Psychology, 26(1), 82-95. https://doi.org/10.1080/10413200.2013.790095

Jannah, M. (2010). Kontribusi metode neuro-linguistic programming pada konsentrasi pelari cepat (sprinter). Jurnal Psikologi Teori dan Terapan, 1(1), 1-7.

Jannah, M. (2012). Kontribusi metode neuro linguistic programming terhadap kemampuan goal setting pelari cepat perorangan. Jurnal Psikologi Teori dan Terapan, 3(1), 42-48.

Jannah, M. (2017). Kecemasan dan konsentrasi pada atlet panahan. Jurnal Psikologi Teori dan Terapan, 8(1), 53-60.

Jannah, M. (2017). Seri pelatihan mental olahraga: Konsentrasi. Unesa University Press. 
Jannah, M. (2020). Energi mental atlet. In M. Jannah, T. R. Moordiningsih, Andayani, \& W. Rahardjo (Eds.), Bahagia dan bermakna (2nd ed., pp. 137-144). CV AA Rizky.

Jannah, M., \& Dewi, D. K. (2021). Penerapan latihan relaksasi otogenik untuk regulasi emosi atlet anggar. Kontribusi: Jurnal Penelitian dan Pengabdian Kepada Masyarakat, 1(2), 76-82.

Jannah, M., Mulyana, O. P., \& Muthohir, T. C. (2015). Psychological profiles of indonesian elite swimmers. Movement Health E Exercise, 4(42), 31-36.

Jopang, J. (2018). Kebijakan pembinaan atlet pusat pendidikan dan latihan pelajar dinas kepemudaan dan olah raga propinsi sulawesi tenggara. Journal Publicuho, 1(1), 1. https://doi.org/10.35817/jpu.v1i1.5846

Kyllo, L. B., \& Landers, D. M. (2016). Goal setting in sport and exercise: A research synthesis to resolve the controversy. Journal of Sport and Exercise Psychology, 17(2), 117-137. https://doi.org/10.1123/jsep.17.2.117

Lavallee, D., Kremer, J., \& Moran, A. (2020). Psychology of sport. Social Sciences in Sport, 3, 4-5. https://doi.org/10.5040/9781492595885.ch-003

Lea, R.G., Qualter, P., Davis, PérezGonzález, J.P. \& Bangee, M. (2018). Trait emotional intelligence and attentional bias for positive emotion: An eye tracking study. Journal of Personality and Individual Differences, 128, 88-93.

Love, S., Kannis-Dymand, L. \& Lovell, G.P. (2018) Metacognitions in triathletes: Associations with attention, state anxiety, and relative performance. Journal of Applied Sport Psychology, 30:4, 421-436, DOI: 10.1080/10413200.2018.1440660

Lu, Q., Li, P., Wu, Q., Liu, X., \& Wu, Y. (2021). Efficiency and enhancement in attention networks of elite shooting and archery athletes. Frontiers in Psychology, 12(March), 1-10. https://doi.org/10.3389/fpsyg.2021.638822

Machida, M., Otten, M., Magyar, T. M., Vealey, R. S., \& Ward, R. M. (2017). Examining multidimensional sport-confidence in athletes and non-athlete sport performers. Journal of Sports Sciences, 35(5), 410-418. https:// doi.org/10.1080/02640414.2016.1167934

Planalp, S. (2015). How important is emotion in everyday interaction? Communicating emotion, 938. https://doi.org/10.1017/cbo9781316257012.003

Purwanto, A., \& Sudargini, Y. (2021). Partial least squares structural squation modeling ( PLS-SEM ) analysis for social and management research: A literature review. Journal of Industrial Engineering E Management Research. 2(4), 114-123.

Putra, M. R. T., \& Jannah, M. (2017). Pengaruh self talk positif terhadap konsentrasi pada atlet panahan. Character: Jurnal Penelitian Psikologi, 4(2), 1-5.

Qiu, F., Pi, Y., Liu, K., Li, X., Zhang, J., Wu, Y. (2018). Influence of sports expertise level on attention in multiple object tracking. PeerJ 6:e5732 https:// doi.org/10.7717/ peerj.5732

Ramayah, T., Cheah, J., Chuah, F., Ting, H., \& Memon, M. A. (2018). Partial least squares structural modeling (PLS-SEM) using SmartPLS 3.0: An updated guide and practical guide to statistical analysis (2nd ed.). Kuala Lumpur, Malaysia: Pearson

Ringle, C. M., Sarstedt, M., Mitchell, R., \& Gudergan, S. P. (2020). Partial least squares structural equation modeling in HRM research. International Journal of Human Resource Management, 31(12), 1617-1643. https:/ / doi.org/10.1080/09585192.2017.1416655

Rodrigues, F, Teixeira, DS, Neiva, HP, Cid, L, Monteiro, D. (2020). The bright and dark sides of motivation as predictors of enjoyment, intention, and exercise persistence. Scand J Med Sci Sports. 30: 787- 800. https:// doi.org/10.1111/sms.13617

Rogier, G., Garofalo, C., \& Velotti, P. (2019). Is emotional suppression always bad? A matter of flexibility and gender differences. Current Psychology, 38(2), 411-420. https://doi.org/10.1007/s12144-017-9623-7

Rooks, J. D., Morrison, A. B., Goolsarran, M., Rogers, S. L., \& Jha, A. P. (2017). “We are talking about practice": The influence of mindfulness vs. relaxation training on athletes' attention 
and well-being over high-demand intervals. Journal of Cognitive Enhancement, 1(2), 141-153. https://doi.org/10.1007/s41465-017-0016-5

Roth, G., Vansteenkiste, M., \& Ryan, R. M. (2019). Integrative emotion regulation: Process and development from a self-determination theory perspective. Development and Psychopathology, 31(3), 945-956. https:// doi.org/10.1017/S0954579419000403

Said, H., \& Jannah, M. (2018). Problematika dan solusi mental dalam olahraga. Surabaya: Unesa University Press.

Scharfstein, M., \& Gaurf. (2013). How emotions influence performance. Journal of Chemical Information and Modeling, 53(9), 1689-1699.

Seaton, C.L., Bottorff, J.L., Jones-Bricker, M., \& Lamont, S. (2018). The role of positive emotion and ego-resilience in determining men's physical activity following a workplace health intervention. American Journal of Men's Health, 12(6) $1916-1928$. https://doi.org/10.1177\%2F1557988318803744

Shet, S. V., Patil, S. V., \& Chandawarkar, M. R. (2019). Competency based superior performance and organizational effectiveness. International Journal of Productivity and Performance Management. https://doi.org/10.1108/ijppm-03-2018-0128

Smith, A. L., \& Ntoumanis, N. (2014). An examination of goal motives and athletes' selfregulatory responses to unattainable goals. International Journal Sport Psychology, 45, 538-558.

Uphill, M. A., Lane, A. M., \& Jones, M. V. (2012). Emotion regulation questionnaire for use with athletes. Psychology of Sport and Exercise, 13(6), 761-770. https://doi.org/10.1016/j.psychsport.2012.05.001

van Raalte, J. L., Vincent, A., \& Brewer, B. W. (2016). Self-talk: Review and sport-specific model. $\begin{array}{lllll}\text { Psychology of Sport and 139-148. } & \text { Exercise, }\end{array}$ https://doi.org/10.1016/j.psychsport.2015.08.004

von Treuer, KM \& Reynolds, N. (2017). A competency model of psychology practice: articulating complex skills and practices. Frontier Education, 2(54). https://doi.org/10.3389/feduc.2017.00054

Weinberg, R. S. (2013). Goal setting in sport and exercise: Research and practical applications. Revista Da Educacao Fisica, 24(2), 171-179. https:// doi.org/10.4025/reveducfis.v24.2.17524

\footnotetext{
Dr. Rachman Widohardhono

Department of Sport Science, Pascasarjana

Universitas Negeri Surabaya,

Kampus Unesa lidah Wetan Surabaya

Email: rachmanwidohardhono@mhs.unesa..ac.id
}

\section{Prof. Dr. Nurhasan}

Department of Sport Education Faculty of Sport Science,

Universitas Negeri Surabaya,

Kampus Unesa lidah Wetan Surabaya

Email: nurhasan@unesa.ac.id

\section{Prof. Dr. Edy Mintarto}

Department of Technology Education Faculty of Science and Technology,

Universitas Negeri Surabaya,

Kampus Unesa lidah Wetan Surabaya

Email: edymintarto@unesa.ac.id

*Dr. Miftakhul Jannah (Corresponding Author)

Department of Psychology, Faculty of Education

Universitas Negeri Surabaya,

Kampus Unesa lidah Wetan Surabaya

Email: miftakhuljannah@unesa.ac.id 